\title{
Hugo Zapata siembra sus flores de piedra en China
}

\section{Fecha de recepción: 25 de octubre de 2011 - Aceptación: 11 de noviembre de 2011}

La introducción de Juan Luis Mejía al libro sobre la obra de Hugo Zapata publicado
por Villegas Editores es una de las más certeras aproximaciones a su mundo.
María Eugenia Niño y Luis Ángel Parra, de la Galería Sextante y el Taller Arte Dos
Gráfico, han sido galeristas y editores de la obra de Hugo Zapata y han facilitado
algunas imágenes para este número de Poliantea.

A todos ellos nuestro reconocimiento.

\section{Juan Gustavo Cobo Borda}

\section{Resumen}

La roca, elemento medular de la obra del artista colombiano Hugo Zapata, se presenta como el eje de la reflexión que en esta edición de Poliantea propone Juan Gustavo Cobo Borda. El escritor se aproxima al trabajo de Zapata y dilucida algunos de sus motivos y temas primordiales.

\section{Abstract}

The stone, the core element of the work of the Colombian artist Hugo Zapata is presented as the axis of the reflec- tion that Juan Gustavo Cobo Borda proposes in this edition of Poliantea. The writer approaches Zapata's work in order to elucidate some of its reasons and key topics.

\section{Palabras clave}

Roca, arte contemporáneo, artistas colombianos, escultura.

\section{Keywords}

Stone, Contemporary Art, Colombian Artists, Sculpture.
A veces tersas, en otras ásperas, en ocasiones segmentadas. Otras dejadas al azar del camino. Dulce en la suavidad que incita al tacto o espejeantes en la difícil aleación entre dureza y reflejo. Pues todas ellas, las piedras de Hugo Zapata ( La Tebaida, Quindío, 1945), parecen encerrar en sí la cavidad de una ofrenda, trátese del agua o de los pigmentos vegetales.

Flores votivas para rendir homenaje a los dioses esquivos, su diálogo es con la naturaleza. No sospechamos que puedan haber sido pulidas ni por la mano del hombre ni por un artilugio mecánico que vibra y estremece el aire. Por el contrario, los nombres primordiales, carbón, lutita, pizarra, mármol, basalto, cuarzo, cristales naturales, asoman más tarde. La primera impresión es de paz y sosiegos. No pensamos en eras geológicas, ni en volcanes al emitir fuego y lava que se petrifica, ni en errantes asteroides que cayeron a tierra. Por el contrario : nos encontramos con ellas, con las piedras de Hugo Zapata, como un refugio, como una luz negra que brilla indeficiente, más allá de árboles, lluvias y nubes. Porque en realidad todo el cielo se ha posado sobre esas vetas y esos relieves, 
y el afán se ha tornado contemplación activa como el agora que dispuso para la Universidad Eafit de Medellín. Aristas, volúmenes, superficies, sombras y texturas como si la cultura, en el silencio que surge después del diálogo, nos reconciliara con el primer principio. La naturaleza misma.

Mujeres y hombres, en cuclillas o tendidos sobre lo grave de la tierra, siguen con desprendimiento las constelaciones de sus sueños. En tal sentido su serie "Amantes", siempre dos piezas paralelas, erguidas en el espacio, armónicas pero diferentes, sugieren el contrapunto de la música, sus disonancias melódicas y su compenetración afectiva.

Quien sembró 70000 yarumos plateados en torno a una represa ( Río Grande II) y configuró un sendero de colores que contrastan (verde, plata, gris, azul) va de lo primordial a

\section{Reseña de autor \\ Juan Gustavo Cobo Borda \\ www.coboborda.org \\ coborda@gmail.com \\ Colaborador Revista Poliantea}

Poeta y ensayista bogotano. Fue director durante una década (1973-1984) de la revista Eco, de la librería Buchholz, y Gaceta, del Instituto Colombiano de Cultura. Ha ocupado cargos diplomáticos en Buenos Aires y Madrid y fue embajador en Grecia. Miembro número de la Academia Colombiana de la Lengua desde 1993, y correspondiente, de la Academia Española. Ha sido jurado tres veces del Premio Juan Rulfo, (Guadalajara, México); del Rómulo Gallegos, (Caracas); del Reina Sofía de poesía iberoamericana (Madrid) y del Neustad, Universidad de Oklahoma, Estados Unidos. Ha colaborado con otras publicaciones, como Plural, de México, $A B C$, de España, y El Nacional de Venezuela.

Entre sus poemarios figuran Consejos para sobrevivir (1974); Todos los poetas son santos (1987); Dibujos hechos al azar de lugares que cruzaron mis ojos (1991) y La musa inclemente (2001), entre otros. Algunas de sus publicaciones son Lengua Erótica: antología poética para hacer el amor(Villegas Editores, 2004), Lector impenitente, El olvidado arte de leer, Enclave de palabras número tres Acosado animal (Politécnico Grancolombiano, 2010), Vargas Llosa: La pasión de narrar (Alfaguara, 2010), sus más recientes publicaciones. lo reflexivo. Del geólogo que percibe en el azar una latente posibilidad creativa al arquitecto que edifica con él una morada o señala, en el jardín o el piso, una orientación que aún no se desprende de su raigambre húmeda pero que ya entra a formar parte de un conjunto, de una estructura. De un lugar pletórico de sentido. La materia y el espíritu. Donde también hierro, concreto o vidrio sirven para sugerir utopías. Velas de barcos, como las egipcias, que atraviesan las puertas del sol en su eclipse y sobrepasan así los raudales incontenibles de la muerte. Les otorgan marco, dimensión y mesura como si el paisaje resultase contenido entre las manos del hombre al señalar la inconmensurable distancia del horizonte y ponerlo a nuestro alcance.

Por ello, muchas de sus piedras, en un vestíbulo, en una casa, en el recodo de una galería de arte, nos obligan a deteneros, con un latido ancestral de emoción y perplejidad. De reflexión y empatía. Ver, sentir y comprender el hábitat donde vivimos, parto y tumba.

En esos mares apresados en un contorno de piedra late una temblorosa isla, que también es de piedra pero ya es de agua. Que vibra, se agita y habla pero continua firme e inmodificable tal como Hugo Zapata, demiurgo, la dispuso en su universo emotivo. El de quien lee a Baudelaire y sus flores del mal pero también traza y ordena en Aracataca, en el Camellón de los Almendros, un lugar de reunión donde bloques de concreto reteñido e hilos de agua rinden y convocan a un homenaje apacible a Gabriel García Márquez y Juan Rulfo. Diálogo, una vez más, del hombre consigo mismo y su entorno.

Escultura pública donde cifrar y descifrar los signos primordiales que desde 
las cavernas de la prehistoria dispuso el hombre sobre sus irregulares muros en sombra gracias a esos pigmentos rojos o naranjas donde, como hizo en su libro de artista, del 2008, con William Ospina, en el Taller Arte Dos Gráficos, darían pie a una aseveración muy suya: "Antes del hombre, la tierra ya escribía”.

Danza fosforescente sobre el telón de fondo de milenios, el agujero negro del origen se puebla de insectos de luz. De siluetas de hojas ya definitivas. De vibraciones espasmódicas de trazos y alfabetos sugerentes que, como en todo el arte de Zapata, tiene plenitud formal, sellada sobre sí misma, pero también apertura a la mirada que acoje, dilata y asimila.

Quizás por ello, ya desde 1977, haría su primer viaje a China, para reencontrarse con ese comienzo antes del principio, en el cual las rocas, que contienen la memoria de todo y se yerguen como estelas para servir de testigos de los hechos de la historia, son paulatinamente borrados por la lluvia. Pero aún así subsisten. Donde el mensaje de la cronología se ha vuelto la impronta de la estética. Lección de humildad que conoce muy bien Zapata, en el devenir cíclico con que asume su tarea, tan compenetrada con la tierra. En Shangai, un jardín de la gente, con 60 flores suyas de hierro, aguarda el renacer de la inexorable primavera. Con razón, China se yergue en los diagnósticos del futuro. Nunca olvidó sus raíces. Sus murallas de piedra son posibles aún de visualizar desde la luna. 